\title{
Dietary intake of cod protein beneficially affects concentrations of urinary markers of kidney function and results in lower urinary loss of amino acids in obese Zucker fa/fa rats
}

\author{
Aslaug Drotningsvik ${ }^{1}, \varnothing_{\text {ivind Midttun }}^{2}$, Adrian McCann ${ }^{2}$, Per Magne Ueland ${ }^{3,4}$, Ingmar Høgøy and \\ Oddrun Anita Gudbrandsen ${ }^{1 *}$ \\ ${ }^{1}$ Dietary Protein Research Group, Department of Clinical Medicine, University of Bergen, 5021 Bergen, Norway \\ ${ }^{2}$ Bevital AS, Jonas Lies veg 87, 5021 Bergen, Norway \\ ${ }^{3}$ Department of Clinical Science, University of Bergen 5021 Bergen, Norway \\ ${ }^{4}$ Laboratory of Clinical Biochemistry, Haukeland University Hospital, 5021 Bergen, Norway \\ ${ }^{5}$ Blue Protein, 5393 Storebø, Norway \\ (Submitted 11 April 2018 - Final revision received 25 June 2018 - Accepted 4 July 2018 - First published online 29 August 2018)
}

\section{Abstract}

Obesity increases the risk for developing kidney disease, and protection of kidneys through changes in diet should be investigated. Fish intake has been associated with reduced risk of developing kidney disease; therefore, we wanted to investigate whether cod protein intake could prevent or delay the development of kidney damage in an obese rat model that spontaneously develops proteinuria and focal segmental glomerulosclerosis. The aim of the study was to investigate any effects of cod protein intake on established markers of kidney function, amino acid composition, protein utilisation and growth in obese Zucker fa/fa rats in the early stage of decreased renal function. Male obese Zucker $\mathrm{fa} / \mathrm{fa}$ rats (HsdOla:Zucker-Lepr) were fed cod muscle proteins in an amount corresponding to $25 \%$ of dietary protein, with the remaining protein from a casein/whey mixture (COD diet). A control group was fed a diet with a casein/whey mixture as the only protein source (CAS diet). The intervention started when rats were 9-10 weeks old, and the rats were fed these diets for 4 weeks. At the end of the study, rats fed the COD diet had lower urine concentration of cystatin C, T-cell immunoglobulin mucin-1 (TIM-1), amino acids, carbamide, uric acid and ammonium and higher concentrations of creatine, trimethylamine $\mathrm{N}$-oxide, 1-methylhistidine and 3-methylhistidine, lower kidney concentration of TIM-1 and showed better growth when compared with the CAS group. To conclude, cod protein may have the potential to delay the development of kidney damage in young obese Zucker rats and to improve protein utilisation and growth.

Key words: Obesity: Kidney function: Cod: Amino acids: Fish protein

The incidence and prevalence of patients with kidney failure are increasing worldwide, and the prevalence of patients in early stages of chronic kidney disease is even higher ${ }^{(1)}$. Obesity increases the risk for developing kidney disease and adversely affects the progress of kidney disease ${ }^{(2)}$, partly explained by impaired glucose regulation ${ }^{(3)}$. Obesity is an important and independent risk factor for development of chronic renal diseases $^{(4-7)}$, and this is of concern as the prevalence of obesity is increasing all over the world ${ }^{(8)}$.

Both paediatric and adult patients with chronic kidney failure are recommended a diet with modest protein restriction to limit the development of toxic nitrogenous metabolites, uraemic symptoms and other metabolic complications ${ }^{(9,10)}$. The dietary advice for these patients in general does not distinguish between different sources of proteins, although intake of fish has been shown to reduce the risk for developing kidney disease both in the general population ${ }^{(11)}$ and in the patients with type 1 diabetes $^{(12)}$. Still, little is known about how various types of dietary proteins may affect kidney function, both in the healthy population and in individuals with high risk of developing impaired kidney function.

The obese Zucker fa/fa rat is a popular rat model for studies on development and treatment of the metabolic syndrome, as this rat presents a range of abnormalities similar to those seen in humans, including insulin resistance, dyslipidaemia, mild glucose intolerance and hypertension ${ }^{(13)}$. Obesity is also associated with proteinuria and focal segmental glomerulosclerosis both in humans and rats and increases the risk of developing renal disease $^{(4-7,14)}$. Obese Zucker rats spontaneously develop proteinuria and focal segmental glomerulosclerosis as they grow

Abbreviations: 1-MeHis, 1-methylhistidine; 3-MeHis, 3-methylhistidine; ACE, angiotensin-converting enzyme; CAS, casein/whey; COD, cod protein; PC, principal component; PCA, principal component analysis; TIM-1, T cell immunoglobulin mucin- 1 ; TMAO, trimethylamine $N$-oxide.

* Corresponding author: O. A. Gudbrandsen, fax +4755975890, email nkjgu@uib.no 
older, ultimately leading to renal failure ${ }^{(15,16)}$, and increased glomerular macrophage density can be observed in these rats already at an age of 4 weeks $^{(17)}$. Proteinuria is developed at around 10 weeks age ${ }^{(14)}$, and indications of decreased renal function are seen at around 12 weeks of age ${ }^{(18,19)}$. Dietary interventions using obese rat models that spontaneously develop renal disease, such as the obese Zucker fa/fa rat, are thus highly relevant to understanding the pathophysiology of obesity-associated morbidity in humans ${ }^{(14,20)}$

The American Heart Association and the Norwegian government recommend a fish intake of 300-450 g/week (two to three dinner meals per week) for the general public ${ }^{(21,22)}$, and the daily average total protein intake for adults in the USA and in Norway is estimated to be $91-96 \mathrm{~g}^{(23,24)}$. Thus, the fish intake following these recommendations corresponds to approximately 60-90 g of fish proteins weekly, amounting to $9-13 \%$ of the total protein intake. Most publications on the effects of fish proteins in rat models have been studying the effects of dietary fish proteins as $100 \%$ of the protein source $^{(25-38)}$. In the present study, fish protein was added to the feed in an amount closer to what is recommended for the human population, that is, $25 \%$ of total protein content. We have recently shown that replacing $25 \%$ of the casein in a regular American Institute of Nutrition (AIN)-93G $\operatorname{diet}^{(39)}$ with cod fillet protein resulted in lower postprandial glucose concentration when fed to obese Zucker $\mathrm{fa} / \mathrm{fa}$ rats ${ }^{(40)}$ and when taken as supplement cod protein reduced postprandial glucose in overweight and obese adults $^{(41)}$. In line with this, others also report on improved glucose regulation after cod protein intake in animal and clinical studies $^{(28,29,42)}$. A persistent high blood glucose concentration over time may damage the glomeruli and thus the capacity of the kidneys to filter the blood; therefore, further studies on the effects of fish proteins on kidney function are warranted. Little is known about the effects of fish proteins on markers of kidney function in this animal model of human obesity, but fat-free protein hydrolysates from herring and salmon by-products ${ }^{(43)}$ as well as salmon fillet ${ }^{(44)}$ beneficially affected markers of kidney function in obese Zucker fa/fa rats.

The aim of the present study was to investigate any effects of muscle proteins from a lean fish species, the Atlantic cod, on markers of kidney function and on the amino acid compositions in plasma and urine in obese Zucker rats in the early stage of decreased renal function. Cod protein was fed to rats in an amount corresponding to $25 \%$ of the total protein in the diet, with the rest of the protein from a casein/whey mixture. The control group was feed a diet with a casein/whey mixture as the only protein source. We hypothesised that dietary cod protein would beneficially affect markers of kidney function, and that amino acid compositions in plasma and urine would reflect the content of amino acids in the cod protein diet and in the control diet that were fed to obese Zucker fa/fa rats.

\section{Methods}

\section{Ethics}

The institutional and national guidelines for the care and use of animals were followed. All experimental procedures involving animals were approved by the Norwegian State Board of
Biological Experiments with Living Animals (approval no. 20124610) and were conducted in accordance with the Norwegian regulation on animal experimentation.

\section{Animals}

A total of twelve male Zucker fa/fa rats (HsdOla:Zucker-Lepr) were obtained from Harlan Laboratories, and randomly assigned to two experimental groups of six rats each with comparable mean body weight. Rats were housed in pairs in Makrolon IV cages (Ehret $\mathrm{GmbH} \&$ Co.) with wood chips bedding and plastic housing, and were subjected to a $12 \mathrm{~h}$ light$12 \mathrm{~h}$ dark cycle (light from 07.00 to 19.00 hours), a constant temperature of $20-23^{\circ} \mathrm{C}$, and relative humidity of $65 \pm 15 \%$. The rats were acclimatised under these conditions before the start of the experiment. The intervention period started when the rats were 9-10 weeks old and weighing 360 (sD 40) g.

\section{Design}

The experimental diets were based on AIN-93G recommendation for growing rats ${ }^{(39)}$ with addition of $1.6 \mathrm{~g}$ methionine $/ \mathrm{kg}$ diet as recommended by Reeves ${ }^{(45)}$ (Table 1 ). All diets contained $20 \mathrm{wt} \%$ proteins, and the control diet (CAS) contained a casein/whey mixture (90\% casein, 10\% whey; Armor Proteines) as the sole protein source. Fish powder made from cod fillet (Atlantic cod, Gadus morhua) (no. 0271, Seagarden AS) was added to the COD diet in an amount providing $25 \mathrm{wt} \%$ of total protein from cod, while casein/whey mixture constituted the remaining $75 \mathrm{wt} \%$ of protein. Casein/whey mixture and cod protein were not hydrolysed before use. All other feed ingredients were purchased from Dyets Inc. Table 1 provides an overview of the experimental diets. Energy and amino acids in the diets were analysed by Nofima BioLab. Creatine in fish the powder and casein/whey mixture was analysed using the Creatine Assay Kit (MAK079) from Sigma-Aldrich, following the manufacturer's instruction for the colorimetric assay. Trimethylamine $\mathrm{N}$-oxide (TMAO) was determined in the fish powder and the casein/whey mixture by the Conway microdiffusion assay ${ }^{(46)}$ (Nofima BioLab).

Table 1. Composition of the experimental diets ( $\mathrm{g} / \mathrm{kg}$ diet)

\begin{tabular}{lcr}
\hline & CAS diet & COD diet \\
\hline Casein protein* & 222.22 & 170.45 \\
Cod protein† & & 55.56 \\
Maize starch & 500.61 & 500.61 \\
Sucrose & 90.00 & 90.00 \\
Cellulose & 50.00 & 50.00 \\
Soyabean oil & 70.00 & 70.00 \\
tert-Butylhydroquinone & 0.014 & 0.014 \\
Mineral mix (AIN-93MX) & 35.00 & 35.00 \\
Vitamin mix (AIN-93VX) & 10.00 & 10.00 \\
L-Met & 1.60 & 1.60 \\
L-Cystine & 3.00 & 3.00 \\
Choline bitartrateł & 2.50 & 2.50 \\
Growth and maintenance supplement§ & 10.00 & 10.00 \\
\hline
\end{tabular}

CAS, casein/whey; COD, cod protein; AIN, American Institute of Nutrition.

* Contains $90 \%$ crude protein.

† Contains $88 \%$ crude protein

¥ Contains $41.1 \%$ choline.

§ Contains vitamin $B_{12}(40 \mathrm{mg} / \mathrm{kg})$ and vitamin $K_{1}(25 \mathrm{mg} / \mathrm{kg})$ mixed with sucrose $(995 \mathrm{~g} / \mathrm{kg})$ and dextrose $(5 \mathrm{~g} / \mathrm{kg})$. 
Feed was given as a powder, and rats always had access to wood chewing sticks. Newly thawed feed was provided every day except Sundays (double doses on Saturdays), and rats had free access to tap water and feed (ad libitum). The intervention period was 4 weeks, and rats were weighed every 7 th day during the intervention period.

Rats were housed in Makrolon IV with grids for $24 \mathrm{~h}$ on the 18th day of the intervention period, without fasting in advance, for collection of urine and measurement of feed and water intake. Feed and water intakes were registered by weighing.

At the end of the feeding period (i.e. after 4 weeks intervention), under fasting conditions for $12 \mathrm{~h}$ with free access to tap water, the rats were euthanised while under anaesthesia with isoflurane (Isoba vet, Intervet; Schering-Plough Animal Health) mixed with nitrous oxide and oxygen. Blood was drawn directly from the heart and was collected in Vacuette Z Serum Clot Activator tubes (Greiner Bio-One) for isolation of serum and in Vacuette K2EDTA tubes (Greiner Bio-One) for isolation of plasma.

Staff handling the rats and conducting the analyses were blinded, and rats were handled and euthanised in random order.

\section{In vitro inhibition of angiotensin-converting enzyme}

To the casein/whey mixture and cod protein was added Trizma buffer ( $50 \mathrm{~mm}, \mathrm{pH} 8 \cdot 0$ ). The casein/whey mixture and cod protein were hydrolysed using trypsin from bovine pancreas (T1426 from Sigma) at $45^{\circ} \mathrm{C}$ for $4 \mathrm{~h}$ as recommended by Shalaby et al. ${ }^{(47)}$. Angiotensin-converting enzyme (ACE) inhibition by protein hydrolysate was measured as described by Shalaby et al. ${ }^{(47)}$, using ACE from rabbit lung (A6778-.25UN from Sigma) and $0.88 \mathrm{~mm}$ furanacroloyl-Phe-Glu-Glu (F7131 from Sigma) as substrate (dissolved in Trizma buffer; $50 \mathrm{~mm}, \mathrm{pH} 7.5$ with $0.3 \mathrm{~m}$ $\mathrm{NaCl}$, all ingredients from Sigma). Immediately before reading, $10 \mu \mathrm{l} \mathrm{ACE}, 10 \mu \mathrm{l}$ protein hydrolysate and $150 \mu \mathrm{l}$ substrate were added to ninety-six-well polystyrene microtitre plates (Corning ${ }^{\circledR}$, $\left.\operatorname{CoStar}^{(\mathbb{B}}\right)$, and plates were read at $340 \mathrm{~nm}$ every 30th second for $30 \mathrm{~min}$ at SpectraMax Plus384 (Molecular Devices) at $37^{\circ} \mathrm{C}$. Protein in hydrolysates were quantified on the Cobas c111 system (Roche Diagnostics $\mathrm{GmbH}$ ) using the TP2 kit from Roche Diagnostics $\mathrm{GmbH}$

\section{Analyses in serum, plasma and urine}

Serum concentrations of creatinine, total protein and carbamide and urine concentrations of creatinine, total protein, carbamide and uric acid were analysed by accredited methods at the Laboratory of Clinical Biochemistry at Haukeland University Hospital. Plasma concentration of ammonium, serum concentration of uric acid and urine concentrations of ammonium and creatinine were analysed using the Cobas c111 system using the appropriate kits from Roche Diagnostics $\mathrm{GmbH}$.

Plasma and urine concentrations of cystatin $\mathrm{C}$ and $\mathrm{T}$ cell immunoglobulin mucin-1 (TIM-1) were quantified using the mouse/rat Cystatin C Quantikine ${ }^{\circledR}$ ELISA (catalogue no. MSCTC0) and the Rat TIM-1/KIM-1/HAVCR Quantikine ${ }^{\circledR}$ ELISA (catalogue no. RKM100) from R\&D Systems, Bio-Techne. Serum vitamin $\mathrm{D}$ was measured by ELISA, using the $25-\mathrm{OH}$ vitamin $\mathrm{D}$ total (Rat) kit (EIA-5532; DRG Instruments GmbH).
Amino acids, selected metabolites of amino acids and potential markers of fish intake were measured in plasma/ serum and urine by Bevital AS (http://www.bevital.no) using GC and liquid chromatography (LC) with tandem mass spectrometry (GC-MS/MS and LC-MS/MS) as previously described $^{(48,49)}$. We analysed 3-hydroxyisobyturate $(3-\mathrm{HIB})^{(49)}$, TMAO, 1-methylhistidine (1-MeHis, $\pi$-methyl-histidine) and 3-methylhistidine (3-MeHis, $\tau$-methyl-histidine) ${ }^{(48)}$ by adding the analytes and isotope labelled internal standards to existing assays. Arginine, $\alpha$-ketoglutaric acid and 3-HIB were measured in plasma but could not be quantified in urine, otherwise the same compounds were analysed in plasma and urine. Sarcosine was measured in serum and urine. Thiamine, riboflavin, nicotinamide, pyridoxal 5'-phosphate, and isoforms and metabolites of these vitamins as well as tryptophan metabolites in the kynurenine pathway, were analysed in plasma by Bevital $\mathrm{AS}^{(49,50)}$. Thiamine, thiamine monophosphate, nicotinic acid, nicotinamide and $\mathrm{N}^{1}$-nicotinamide with isotope labelled internal standards were added to the previously published assay ${ }^{(50)}$.

\section{Analyses of $T$ cell immunoglobulin mucin-1 in kidney homogenate}

Kidneys were homogenised in TRIS-buffer ( $\mathrm{pH} 7 \cdot 8$ ). TIM-1 in kidney homogenate was measured with the Rat TIM-1/KIM-1/ HAVCR Quantikine ${ }^{\circledR}$ ELISA kit. Kidney protein content was measured with the Bradford dye-binding method $^{(51)}$ using Protein Assay Dye Reagent (Bio-Rad Laboratories) with bovine serum albumin (Bio-Rad Protein Assay Standard II, Bio-Rad Laboratories) as standard.

\section{Sample size}

This study was designed to investigate the effects of a diet containing cod protein on glucose regulation, lipid metabolism and growth. Based on our previous findings that cod protein seems to improve postprandial glucose regulation and growth ${ }^{(40)}$, and the knowledge that obese Zucker fa/fa rats spontaneously develop kidney failure ${ }^{(15,16)}$, the primary outcome of the present study was to investigate whether these cod protein fed Zucker fa/fa rats had a better kidney function and better utilisation of dietary protein when compared with rats fed a control diet. Instead of conducting a new rat experiment, and in line with The Three Rs of animal experiments (reduction, refinement and replacement), we chose to do more analyses using the biological samples from the same experiment. Therefore, no power analysis has been conducted for the present study.

\section{Statistical analysis}

Data were tested for normality using the Shapiro-Wilk test, and since most data were normally distributed they were evaluated by unpaired Student's $t$ test and the cut-off level for statistical significance was set to $0 \cdot 05$. CAS-fed rats served as controls. Data are presented as means with standard deviations for six rats per group for all serum/plasma analyses. One urine sample from a rat in the CAS group fell on the floor after collection and was discarded; therefore, only five urine samples from the CAS group were analysed whereas six urine samples from the COD group were 
analysed. Patterns in biomarker concentrations were investigated separately in urine and plasma by performing principal component analysis (PCA) on matrixes containing centred and standardised biomarker concentrations. Statistical analyses were performed using SPSS version 25 for Windows; SPSS Inc., and R version 3.2.3 (http:// www.r-project.org) with the prcomp package.

\section{Results}

\section{Diets, growth and energy intake}

The contents of the indispensable amino acids histidine, isoleucine, leucine, threonine, tryptophan, phenylalanine and valine were comparable in the CAS and COD diets (i.e. $<1 \mathrm{~g} / \mathrm{kg}$ diet difference), whereas lysine, methionine and the conditionally essential amino acid arginine ${ }^{(52)}$ were found in higher concentrations in the COD diet (Table 2). Some differences were also seen between the two diets for the non-essential amino acids; the COD diet contained higher concentrations of aspartic acid + asparagine, glycine and alanine and lower concentrations of glutamic acid+glutamine and proline when compared with the CAS diet. The COD diet contained $0.25 \mathrm{~g}$ EPA and $0.62 \mathrm{~g}$ DHA per $\mathrm{kg}$, whereas long-chain n-3 PUFA were not found in the CAS $\operatorname{diet}^{(40)}$.

Creatine and TMAO were found in cod protein powder (12.5 $\mu \mathrm{g}$ creatine and $5.4 \mu \mathrm{g}$ TMAO per mg protein) but not in the casein/whey mixture. The COD protein had a stronger ACE-inhibiting capacity when compared with the CAS protein (IC50 was 165 and $253 \mu \mathrm{g} / \mathrm{ml}$ for COD and CAS proteins, respectively, mean of three measurements with $\mathrm{CV}<5 \%$ ).

Body weight at baseline was similar in both groups (Fig. 1). COD-fed rats had gained significantly more weight after 3 and 4 weeks of intervention ( $P$ values of 0.018 and 0.016 , respectively) and tended to have higher body weight already 2 weeks into the intervention period $(P=0 \cdot 067)$ when compared with CAS-fed rats. When comparing the weight development curves over the 4 week intervention period, the growth was

Table 2. Amino acids in diets ( $\mathrm{g} / \mathrm{kg}$ diet) ${ }^{\star}$

\begin{tabular}{|c|c|c|}
\hline & CAS diet & COD diet \\
\hline Ala & $6 \cdot 6$ & $7 \cdot 6$ \\
\hline Arg & $7 \cdot 1$ & $8 \cdot 3$ \\
\hline$A s p+A s n$ & $13 \cdot 6$ & $16 \cdot 8$ \\
\hline Cys + cystine & 4.4 & $5 \cdot 0$ \\
\hline Glu + Gin & $43 \cdot 3$ & $42 \cdot 0$ \\
\hline Gly & $3 \cdot 8$ & $5 \cdot 4$ \\
\hline His & $5 \cdot 7$ & 5.4 \\
\hline Ile & $10 \cdot 8$ & $10 \cdot 5$ \\
\hline Leu & $20 \cdot 2$ & $19 \cdot 3$ \\
\hline Lys & $16 \cdot 6$ & $17 \cdot 7$ \\
\hline Met & $7 \cdot 0$ & $8 \cdot 5$ \\
\hline Phe & $10 \cdot 4$ & $9 \cdot 7$ \\
\hline Pro & $21 \cdot 3$ & $18 \cdot 0$ \\
\hline Ser & $11 \cdot 6$ & $10 \cdot 9$ \\
\hline Thr & 8.9 & $9 \cdot 1$ \\
\hline Trp & $2 \cdot 2$ & $2 \cdot 2$ \\
\hline Tyr & $9 \cdot 1$ & $8 \cdot 2$ \\
\hline Val & $13 \cdot 3$ & $12 \cdot 5$ \\
\hline
\end{tabular}

CAS, casein/whey; COD, cod protein.

* Means of two measurements; deviations were $<5 \%$ between parallels. significantly larger in COD-fed rats when compared with CASfed rats (slope 41.4 (SD 3.4) and 35.5 (SD 4.1) g/week, respectively, $P=0.022$ )

The intakes of energy (1280 (sD 74) and 1270 (sD 77) kJ/kg body weight per $24 \mathrm{~h}$, respectively, $P=0.82$ ) and total amino acids (14.9 (sD 0.9) and 15.0(sD 0.9) g/kg body weight per $24 \mathrm{~h}$, respectively, $P=0.91$ ) were similar between rats fed the CAS and COD diets. Water intake was similar between the groups, as previously published ${ }^{(40)}$. The weights of kidneys, white adipose tissues and thigh skeletal muscle (all relative to body weight) and body weight-to-square body length were similar between the groups ${ }^{(40)}$. These observations indicate that rats fed the CAS or COD diets had similar body composition and that the higher body weight in COD-fed rats was not a result of higher adiposity.

\section{Analyses in urine and kidneys}

Urine concentrations (adjusted for creatinine concentration) of cystatin C and TIM-1 (Fig. 2(a) and (b)) and total sum of amino acids, carbamide, uric acid and ammonium (Table 3) were significantly lower in COD-fed rats when compared with the CAS group, whereas no difference was seen between groups for concentration of urinary protein. In addition, we found a significantly lower amount of TIM-1 in kidneys from COD-fed rats when compared with CAS-fed rats (12 (sD 11) and 6 (sD 1) pg TIM-1 per mg protein, respectively, $P=0.045)$.

Using PCA for combined analysis of all analytes measured in urine (concentrations relative to creatinine concentration), the first two principal components (PC) explained 80.3\% (65.2 and $15 \cdot 1 \%$, respectively) of the variation in the dataset, with a clear separation of the CAS and COD groups (Fig. 3(a) and (b)).

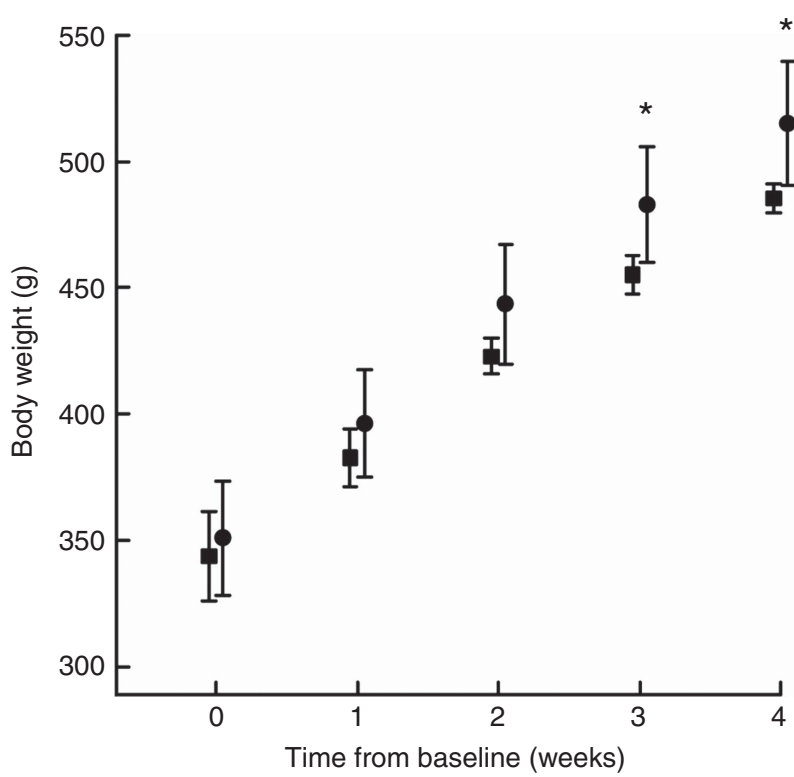

Fig. 1. Body weight measured at baseline (week 0), and after 1, 2, 3 and 4 weeks of intervention for rats fed a control diet (casein/whey; CAS; $\square$ ) or cod diet (COD; ). Values are means ( $n 6$ in CAS group and $n 6$ in COD group), with standard deviations represented by vertical bars. * Mean value was significantly different from that of the CAS group $(P<0.05$, evaluated by independent-samples $t$ test assuming equal variances). 
(a)

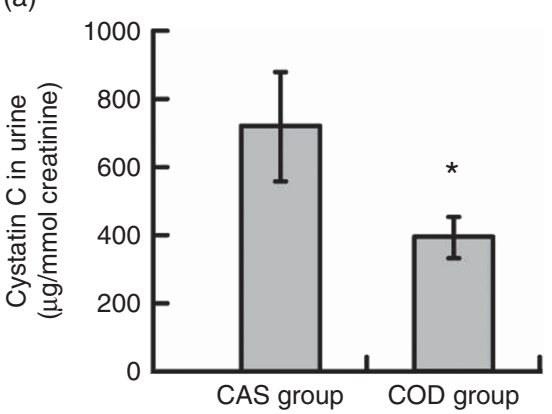

(c)

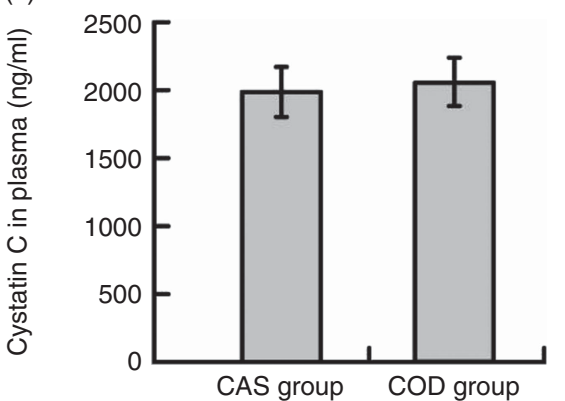

(b)

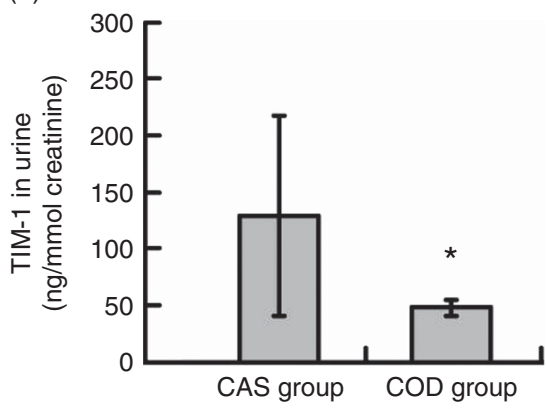

(d)

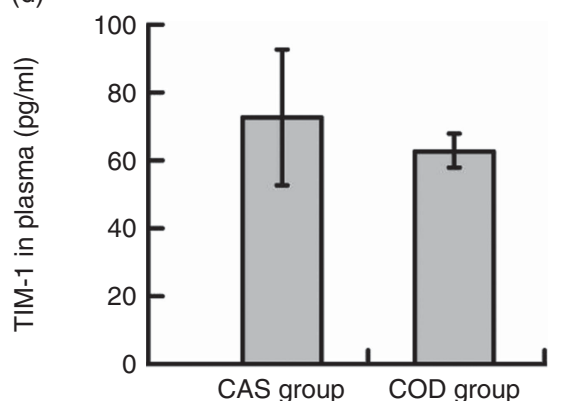

Fig. 2. Cystatin C (a) and T cell immunoglobulin mucin-1 (TIM-1) (b) in urine, and cystatin C (c) and TIM-1 (d) in plasma. Values are means, with standard deviations represented by vertical bars. Plasma values are shown for $n 6$ rats in the control diet (casein/whey; CAS) group and $n 6$ rats in the cod diet (COD) group. Urine values are shown for $n 5$ rats in the CAS group and $n 6$ rats in the COD group. * Mean value in the COD group was significantly different from that of the CAS group $(P<0.05$; evaluated by independent-samples $t$ test assuming equal variances).

Table 3. Nitrogen-containing compounds measured in urine* (Mean values and standard deviations)

\begin{tabular}{|c|c|c|c|c|c|}
\hline & \multicolumn{2}{|c|}{ CAS group } & \multicolumn{2}{|c|}{ COD group } & \multirow[b]{2}{*}{$P$} \\
\hline & Mean & SD & Mean & SD & \\
\hline $\begin{array}{l}\text { Total protein } \\
\text { (mg/mmol creatinine) }\end{array}$ & 321 & 127 & 251 & 58 & 0.29 \\
\hline $\begin{array}{l}\text { Total sum amino acids } \\
(\mu \mathrm{mol} / \mathrm{mmol} \text { creatinine })\end{array}$ & 646 & 110 & 433 & 29 & 0.0013 \\
\hline $\begin{array}{l}\text { Carbamide } \\
\qquad(\mathrm{mmol} / \mathrm{mmol} \text { creatinine })\end{array}$ & 301 & 30 & 216 & 8 & 0.000090 \\
\hline $\begin{array}{l}\text { Uric acid } \\
\qquad(\mathrm{mmol} / \mathrm{mmol} \text { creatinine })\end{array}$ & $0 \cdot 24$ & 0.05 & $0 \cdot 16$ & 0.02 & 0.0075 \\
\hline $\begin{array}{l}\text { Ammonium } \\
\qquad(\mu \mathrm{mol} / \mathrm{mmol} \text { creatinine })\end{array}$ & 18 & 3 & 13 & 1 & 0.010 \\
\hline
\end{tabular}

Compared with the CAS group, urine from COD-fed rats was characterised by high relative concentrations of creatine, TMAO, 1-MeHis and 3-MeHis, which originates from the cod protein, and lower concentrations of all amino acids and metabolites thereof. For more details on concentrations of the individual compounds in urine, see Table 4.

\section{Analyses in serum and plasma}

Circulating concentrations of cystatin C and TIM-1 (Fig. 2(c) and (d)) and of creatinine, total protein, the total amount of amino acids, carbamide and ammonium (Table 5) were similar in the
CAS and COD groups. PCA of circulating metabolites showed that PC1 and PC2 explained only 26.9 and $16.6 \%$, respectively, of the variance in the dataset when all analytes measured in serum and plasma are included, with no clear separation between the dietary groups (data not presented). Table 4 shows the concentrations of amino acids and metabolites thereof demonstrating significantly lower concentrations of glycine, aspartic acid and sarcosine and significantly higher concentrations of arginine, creatine, 1-MeHis and 3-MeHis in the COD group compared with the CAS group. Groups were similar with regard to circulating concentrations of micronutrients and tryptophan with metabolites (online Supplementary Table S1), and PCA of micronutrients and tryptophan 
(a)

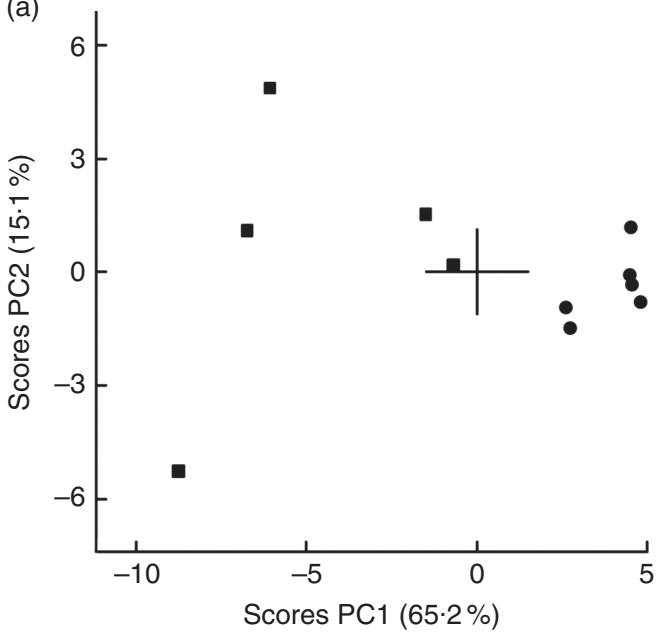

(b)

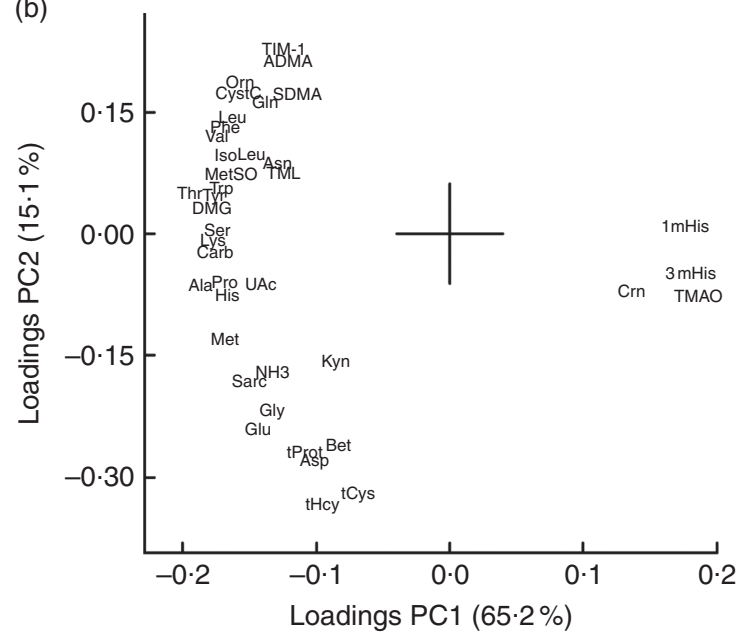

Fig. 3. Scores (a) and loadings (b) from the first two principal components (PC1 and PC2) obtained from principal component analysis using centred and standardised biomarker concentrations (relative to creatinine) in urine. Values are means shown for $n 5$ in the control diet (casein/whey; CAS) group and $n 6$ in the cod diet (COD) group. The score plot (a) shows the rat groups by feed $(\boldsymbol{\square}=\mathrm{CAS}$ and $=\mathrm{COD})$, while the loading plot (b) shows the biomarkers. ADMA, asymmetric dimethylarginine; Ala, alanine; Asn, asparagine; Asp, aspartic acid; Bet, betaine; Carb, carbamide; Crn, creatine; CystC, cystatin C; DMG, dimethylglycine; Gln, glutathione; Glu, glutamine; Gly, glycine; His, histidine; IsoLeu, isoleucine; TIM-1, T-cell immunoglobulin mucin-1; Kyn, kynurenine; Leu, leucine; Lys, lysine; 1mHis, 1-methylhistidine; 3mHis, 3-methylhistidine; Met, methionine; MetSO, methionine sulfoxide; $\mathrm{NH}_{3}$, ammonium; Orn, ornithine; PC, principal component; Phe, phenylalanine; Pro, proline; Sarc, sarcosine; SDMA, symmetric dimethylarginine; Ser, serine; tCys, total cysteine; tHcy, total homocysteine; Thr, threonine; TMAO, trimethylamine $N$-oxide; TML, trimethyllysine; tProt, total protein; Trp, tryptophan; Tyr, tyrosine; UAc, uric acid; Val, valine.

metabolites showed no clear separation between the CAS and COD groups (PC1; 32.0, PC2; 19.9, data not presented).

\section{Discussion}

Obesity increases the risk of developing renal disease in humans and rats ${ }^{(4-7,14)}$, whereas consumption of proteins from fish is associated with lower prevalence of kidney disease ${ }^{(11,12)}$. In the present study, we show for the first time that diets that are different only with regard to source of protein have very different effects on growth as well as on urine concentrations of cystatin C and TIM-1 (established markers of kidney function), amount of TIM-1 in kidney and urinary excretion of amino acids when fed to obese Zucker fa/fa rats that spontaneously develop renal disease $\mathrm{s}^{(14,20)}$. Findings in the present study indicate that cod protein may have the potential to delay the development of kidney damage in obese Zucker rats and to improve protein utilisation.

The presence of proteins and amino acids in urine are among the earliest sign of almost all renal diseases in both humans and animals ${ }^{(53-55)}$. The obese Zucker fa/fa rat was chosen as a model in the present study since this rat develops proteinuria already at around 10 weeks age ${ }^{(14)}$, that is, at the same age as the rats in the present study at start of intervention. Protein was found in urine from both COD- and CAS-fed rats, with no difference between the groups, suggesting that renal dysfunction was evident in both groups. The urine cystatin $\mathrm{C}$ concentration is a specific marker of tubular dysfunction ${ }^{(56)}$ and is strongly associated with renal dysfunction in patients with obesity ${ }^{(57)}$. Urine cystatin C concentration has also been shown to be a good marker of renal damage in diabetic Zucker fa/fa rats ${ }^{(58)}$. TIM-1 has emerged as a useful early indicator of tubular injury as TIM-1 is not detectable in normal kidney tissue or urine but is expressed on the proximal tubule apical membrane in response to renal injury leading to rapid increase in urine concentration ${ }^{(59,60)}$, even before morphological changes are detected ${ }^{(61)}$. TIM-1 was found in detectable concentrations in urine and kidneys from both CAS- and COD-fed rats (aged 13-14 weeks at euthanasia) in the present study, suggesting that both intervention groups experienced kidney injury, which was expected since decreased renal function is seen in obese Zucker fa/fa rats at around 12 weeks age ${ }^{(18,19)}$. Since the urine concentrations of both cystatin C and TIM-1 as well as the amount of TIM-1 in kidneys were significantly lower in the COD group compared with in the CAS group, this could suggest that the COD diet may have offered some protection against the development of kidney injury in the present study.

A commonly used marker of kidney function is serum creatinine, which is produced at a relatively constant rate mainly depending on the muscle mass, muscle function, diet and health status ${ }^{(62)}$. Serum creatinine concentration may remain normal until about $50 \%$ of kidney function is lost ${ }^{(62)}$, with a lag time between the injury and a rise in serum concentration ${ }^{(59)}$. Therefore, serum creatinine is no longer regarded as a sensitive marker of kidney function ${ }^{(63)}$, and more sensitive markers of renal tubular injury are warranted to discover early stages of kidney injury, as the kidney is most amendable to treatment in the early stages of the disease. Serum cystatin C is considered to be a better marker than serum creatinine for early detection of reduced renal function ${ }^{(64)}$; however, no differences were seen between the CAS and COD groups for circulating concentrations of creatinine and cystatin $\mathrm{C}$.

Rats fed the COD diet grew significantly more during the 4-week intervention period when compared with CAS-fed rats, with similar body weight-to-square body length as well as weights of white adipose tissues and thigh skeletal muscle relative to body weight between the groups ${ }^{(40)}$. Lack of vitamins 
Table 4. Amino acids and metabolites thereof and potential markers of fish protein intake* (Mean values and standard deviations)

\begin{tabular}{|c|c|c|c|c|c|c|c|c|c|c|}
\hline & \multicolumn{5}{|c|}{ Urine ( $\mu \mathrm{mol} / \mathrm{mmol}$ creatinine) } & \multicolumn{5}{|c|}{ Plasma† $(\mu \mathrm{mol} / \mathrm{l})$} \\
\hline & \multicolumn{2}{|c|}{ CAS group } & \multicolumn{2}{|c|}{ COD group } & \multirow[b]{2}{*}{$P$} & \multicolumn{2}{|c|}{ CAS group } & \multicolumn{2}{|c|}{ COD group } & \multirow[b]{2}{*}{$P$} \\
\hline & Mean & SD & Mean & SD & & Mean & SD & Mean & SD & \\
\hline Ala & $67 \cdot 1$ & $11 \cdot 3$ & 43.9 & $1 \cdot 7$ & 0.00072 & 429 & 63 & 500 & 64 & 0.079 \\
\hline Argt & ND & & ND & & & 113 & 20 & 137 & 14 & 0.037 \\
\hline Asn & $17 \cdot 7$ & 2.9 & $12 \cdot 8$ & $2 \cdot 0$ & 0.0089 & $55 \cdot 6$ & $1 \cdot 7$ & 57 & 4.5 & 0.50 \\
\hline Asp & $6 \cdot 1$ & $3 \cdot 7$ & 4.7 & $1 \cdot 2$ & 0.39 & 14.9 & $2 \cdot 0$ & $11 \cdot 7$ & $2 \cdot 5$ & 0.034 \\
\hline Betaine & $91 \cdot 1$ & $20 \cdot 3$ & $78 \cdot 9$ & $5 \cdot 8$ & 0.19 & $82 \cdot 1$ & $9 \cdot 4$ & $80 \cdot 2$ & $8 \cdot 8$ & 0.72 \\
\hline Creatine & $6 \cdot 8$ & 1.9 & 49.9 & $35 \cdot 2$ & 0.024 & $67 \cdot 2$ & 13.5 & 143.5 & $27 \cdot 7$ & 0.00012 \\
\hline Cys (total) & 54 & 19 & 52 & 8 & 0.80 & 205 & 16 & 214 & 12 & 0.30 \\
\hline Asymmetric dimethyl-arginine & 0.21 & 0.09 & 0.13 & 0.02 & 0.051 & 0.72 & 0.07 & 0.79 & 0.09 & 0.17 \\
\hline Symmetric dimethyl-arginine & 3.3 & 0.7 & 2.8 & $0 \cdot 2$ & 0.13 & 0.38 & 0.03 & 0.40 & 0.06 & 0.58 \\
\hline Dimethyl-glycine & $78 \cdot 6$ & $12 \cdot 4$ & $44 \cdot 6$ & $5 \cdot 8$ & 0.00020 & $11 \cdot 4$ & $1 \cdot 2$ & $11 \cdot 2$ & 1.9 & 0.83 \\
\hline Gln & $84 \cdot 6$ & $15 \cdot 2$ & $58 \cdot 6$ & $8 \cdot 1$ & 0.0055 & 524 & 53 & 479 & 47 & 0.15 \\
\hline Glu & $35 \cdot 5$ & $20 \cdot 7$ & $16 \cdot 6$ & 2.5 & 0.052 & 156 & 27 & 141 & 15 & 0.26 \\
\hline$a$-Ketoglutaric acid $\dagger$ & ND & & ND & & & 68.5 & $7 \cdot 6$ & 58.4 & $5 \cdot 4$ & 0.025 \\
\hline Gly & 54 & 16 & 43 & 7 & $0 \cdot 15$ & 159 & 22 & 133 & 15 & 0.035 \\
\hline His & $14 \cdot 1$ & 1.9 & $10 \cdot 5$ & 0.9 & 0.0025 & $51 \cdot 7$ & $1 \cdot 8$ & $52 \cdot 6$ & $4 \cdot 0$ & 0.62 \\
\hline 1-Methyl-histidine & $5 \cdot 1$ & 2.5 & $14 \cdot 0$ & $1 \cdot 2$ & 0.000026 & $8 \cdot 3$ & 0.88 & $15 \cdot 3$ & 1.51 & 0.0000019 \\
\hline 3-Methyl-histidine & $6 \cdot 7$ & 1.4 & $19 \cdot 6$ & 1.5 & 0.00000016 & $4 \cdot 25$ & 0.38 & $5 \cdot 68$ & 0.85 & 0.0038 \\
\hline Homocysteine (total) & 4.43 & 1.90 & 3.63 & 0.59 & 0.35 & 3.64 & 0.24 & 3.54 & 0.27 & 0.51 \\
\hline 3-Hydroxy-isobutyrate† & ND & & ND & & & $26 \cdot 3$ & $1 \cdot 1$ & $26 \cdot 0$ & $2 \cdot 8$ & 0.83 \\
\hline Ile & $12 \cdot 6$ & $2 \cdot 6$ & $7 \cdot 0$ & 0.8 & 0.00064 & 89 & 11 & 101 & 13 & 0.13 \\
\hline Kynurenine & 0.26 & 0.11 & 0.23 & 0.09 & 0.64 & $2 \cdot 26$ & 0.21 & 2.04 & 0.28 & 0.15 \\
\hline Leu & $29 \cdot 9$ & $7 \cdot 5$ & $17 \cdot 0$ & 1.5 & 0.0025 & 126 & 12 & 145 & 19 & 0.072 \\
\hline Lys & $59 \cdot 3$ & $10 \cdot 1$ & $40 \cdot 9$ & $2 \cdot 1$ & 0.0017 & 356 & 39 & 391 & 46 & $0 \cdot 18$ \\
\hline Met & 10 & 3 & 5 & 1 & 0.0066 & $54 \cdot 7$ & 3.3 & $54 \cdot 8$ & 4.9 & 0.95 \\
\hline Methionine sulfoxide & $5 \cdot 2$ & 1.8 & $2 \cdot 1$ & 0.3 & 0.0024 & 1.33 & 0.28 & 1.72 & 0.86 & 0.32 \\
\hline Ornithine & 4.9 & $1 \cdot 2$ & $2 \cdot 7$ & 0.5 & 0.0020 & 61.6 & $16 \cdot 3$ & $48 \cdot 6$ & $5 \cdot 9$ & 0.10 \\
\hline Phe & $13 \cdot 4$ & 3.0 & $7 \cdot 3$ & 0.6 & 0.00088 & $69 \cdot 6$ & $1 \cdot 8$ & $72 \cdot 1$ & $3 \cdot 3$ & 0.12 \\
\hline Pro & 47 & 8 & 28 & 1 & 0.00025 & 152 & 15 & 163 & 32 & 0.42 \\
\hline Sarcosine & 5.56 & 0.99 & 4.63 & 0.36 & 0.059 & 0.80 & 0.11 & 0.67 & 0.07 & 0.033 \\
\hline Ser & 30.5 & $6 \cdot 8$ & $20 \cdot 4$ & $1 \cdot 6$ & 0.0062 & 253 & 20 & 234 & 13 & 0.072 \\
\hline Thr & $59 \cdot 5$ & $7 \cdot 0$ & $37 \cdot 0$ & $2 \cdot 4$ & 0.000040 & 264 & 22 & 247 & 31 & 0.28 \\
\hline Trimethylamine $\mathrm{N}$-oxide & 75 & 31 & 927 & 63 & $5.3 \times 10^{-10}$ & 3.84 & 1.48 & 4.99 & $1 \cdot 72$ & 0.24 \\
\hline Trimethyl-lysine & $10 \cdot 9$ & 0.7 & 8.0 & 1.5 & 0.0030 & $1 \cdot 24$ & 0.13 & 1.39 & 0.2 & 0.16 \\
\hline Trp & 3.41 & 1.05 & 1.86 & 0.26 & 0.0062 & 104 & 6 & 99 & 10 & 0.31 \\
\hline Tyr & $18 \cdot 9$ & $5 \cdot 2$ & $9 \cdot 9$ & $1 \cdot 6$ & 0.0029 & 71.9 & $6 \cdot 5$ & 71.2 & $10 \cdot 6$ & 0.90 \\
\hline Val & $27 \cdot 7$ & $5 \cdot 0$ & $15 \cdot 6$ & $1 \cdot 3$ & 0.00027 & 191 & 20 & 224 & 35 & 0.071 \\
\hline
\end{tabular}

CAS, casein/whey; COD, cod protein; ND, not determined.

* Plasma values are shown for $n 6$ rats in the CAS group and $n 6$ rats in the COD group. Urine values are shown for $n 5$ rats in the CAS group and $n 6$ rats in the COD group. $P<0.05$ was considered significant. Groups are compared using independent-samples $t$ test assuming equal variances.

$\dagger$ The biochemical assays do not allow for quantifications of arginine, $a$-ketoglutaric acid and 3-hydroxyisobutyrate in urine.

$\ddagger$ Sarcosine was measured in serum.

Table 5. Circulating analytes that are relevant to kidney function*

(Mean values and standard deviations)

\begin{tabular}{|c|c|c|c|c|c|}
\hline & \multicolumn{2}{|c|}{ CAS group } & \multicolumn{2}{|c|}{ COD group } & \multirow[b]{2}{*}{$P$} \\
\hline & Mean & SD & Mean & SD & \\
\hline Serum creatinine $(\mu \mathrm{mol} / \mathrm{l})$ & $18 \cdot 2$ & 1.5 & $17 \cdot 6$ & $1 \cdot 3$ & 0.67 \\
\hline Serum total protein $(\mathrm{g} / \mathrm{l})$ & 63 & 2 & 62 & 2 & 0.52 \\
\hline Plasma total sum amino acids $(\mu \mathrm{mol} / \mathrm{l})$ & 3455 & 189 & 3539 & 212 & 0.49 \\
\hline Serum carbamide $(\mathrm{mmol} / \mathrm{l})$ & $6 \cdot 2$ & $1 \cdot 0$ & $6 \cdot 1$ & 0.7 & 0.92 \\
\hline Plasma ammonium ( $\mu \mathrm{mol} / \mathrm{l})$ & 56 & 7 & 58 & 7 & 0.55 \\
\hline Serum uric acid $(\mu \mathrm{mol} / \mathrm{l})$ & 58 & 14 & 47 & 6 & 0.11 \\
\hline
\end{tabular}

could impede growth in young rats, and therefore, we measured plasma concentrations of fat soluble vitamins, B vitamins and metabolites of these, but no differences were seen between the groups for any of these micronutrients. Under normal conditions, amino acids can be metabolised, degraded to carbamide or they can become building blocks in proteins. 
Typically, the $\mathrm{N}$ excreted in urine is mainly in the form of carbamide and ammonia, with $<1 \%$ of renal $\mathrm{N}$ in the form of other compounds such as uric acid, proteins, amino acids, nitric oxide metabolites and nitrates, and the carbamide production normally reflects the protein intake. Here, we found that the urinary excretions (relative to creatinine concentration) of the small N-containing compounds carbamide, uric acid, ammonium and the majority of free amino acids were significantly lower in COD-fed rats when compared with CAS-fed rats, whereas no difference was seen between groups for urinary total protein concentration. Circulating concentrations of creatinine, total protein, carbamide, ammonium and free amino acids were, however, not different between the groups. These findings, especially regarding the lower urinary excretion of $\mathrm{N}$-containing compounds in relation to better growth in CODfed rats concomitant with similar intakes of energy and proteins from diets in the CAS and COD groups, indicate that cod protein is better utilised for growth when compared with the casein/ whey mixture used in the CAS diet.

Differences in amino acid compositions in the CAS and COD diets were, in general, not reflected in the plasma concentrations of amino acids in rats fed these diets. The COD diet contained more lysine, methionine, arginine, aspartic acid +asparagine, glycine and alanine and less glutamic acid + glutamine and proline when compared with the CAS diet. The higher arginine and lower aspartic acid concentrations in plasma from COD-fed rats may be a reflection of the dietary concentrations of these amino acids, whereas the lower plasma glycine in the COD group was not expected as the glycine concentration was higher in the COD diet when compared with the CAS diet.

Most of the amino acids that are filtered by the glomeruli will normally be reabsorbed by the tubules and are not excreted in urine $^{(65,66)}$. Aminoaciduria occurs before proteinuria as kidney dysfunction develops and is an early index of renal tubular damage with reduced tubular reabsorption of amino acids ${ }^{(54,55)}$. Also, 1-MeHis, 3-MeHis, creatine and TMAO are small molecules that are cleared from plasma by the kidneys and excreted in urine. Anserine, which is found in cod and rat skeletal muscle but not in cows' milk ${ }^{(67-70)}$, is degraded to 1-MeHis, whereas 3MeHis is released on breakdown of actin and myosin. Therefore, 1-MeHis and 3-MeHis found in rats' plasma and urine may originate from either dietary intake or proteolysis of the rats' own muscles. These methylhistidines are not reutilised for protein synthesis or metabolised and are, therefore, excreted in the urine and have been proposed to be useful as biomarkers of meat intake $^{(71)}$. In line with this, COD-fed rats were characterised by higher concentrations of both 1-MeHis and 3-MeHis in plasma and urine compared with CAS-fed rats, probably as a result of higher fish protein intake and not as a consequence of muscle protein degradation. Creatine and TMAO (or its precursor trimethylamine) can be obtained from the diet or produced in the body. Cod is a good source of both creatine ${ }^{(72)}$ and TMAO ${ }^{(67,73)}$, whereas cows' milk proteins contain little of these compounds. High creatine intake is reflected in high serum concentrations and increased urine excretion of creatine but does not seem to affect established markers of kidney disease in rodents ${ }^{(74,75)}$. The results from PCA showed that COD-fed rats, in general, had lower urine concentrations of all amino acids and related compounds, but higher 1-MeHis, 3-MeHis, creatine and TMAO when compared with CAS-fed rats, that is, no direct correlation was seen between intake and urinary excretion of amino acids. The observed associations between the intake of COD and urine concentrations of 1-MeHis, 3-MeHis, creatine and TMAO suggest that these compounds should be further investigated as markers of lean fish intake. Reduction of circulating TMAO has been suggested as a therapeutic treatment of renal disease, since circulating TMAO concentration is increased as kidney function decreases in patients with renal dysfunction, and the risk of developing renal disease is increased in persons with high plasma TMAO ${ }^{(76)}$. However, some studies report no causal association of TMAO with morbidity or mortality from renal diseases $^{(76)}$. When glomerular filtration and plasma clearance of TMAO are reduced, TMAO will accumulate in the circulation. Cod fillet, unlike dairy products, contains high amounts of TMAO $^{(67,73)}$, but no difference was seen between rats fed the CAS and COD diets for plasma TMAO concentration, thus indicating that the glomerular filtration of TMAO was sufficient avoid accumulation in circulation in the latter group.

Patients with kidney disease are often treated with angiotensinI-converting enzyme inhibitors to reduce blood pressure and protect kidneys ${ }^{(77-79)}$. ACE catalyses the conversion of angiotensin-I to the potent vasoconstrictor angiotensin-II, and ACE inhibitors; therefore, it plays an important role in the regulation of systemic blood pressure and protect kidney through the reduction of glomerular pressure by dilatation of the efferent arteriole and inhibition of the non-haemodynamic profibrotic effects of angiotensin $\mathrm{II}^{(80,81)}$. Peptides with ACE-inhibiting properties in vitro have been identified in muscle, skin and frame from various fish species ${ }^{(82)}$. In the present study, we measured the ACE-inhibiting capacity of the proteins used in the diets, and we found that COD protein more efficiently inhibited ACE when compared with the CAS protein. Thus, COD may protect kidney tissue through inhibition of ACE.

This study has some strengths and limitations. Strengths include the measurement of many biomarkers related to renal function, in both urine and serum/plasma. By measuring circulating micronutrient concentrations, we also demonstrated that better growth in the COD group was not due to a better micronutrient status. This study was originally designed to investigate the effects of cod protein intake on growth, lipid metabolism and glucose regulation in obese Zucker $\mathrm{fa} / \mathrm{fa}$ rats ${ }^{(40)}$. Therefore, a limitation to the present study is that we do not have histopathological data from the kidneys. However, the finding of lower urinary concentration of TIM-1 in COD-fed rats was supported by lower kidney concentration of TIM-1 in these rats when compared with CAS-fed rats.

In conclusion, in line with our hypothesis, cod protein feeding led to lower urine concentrations of cystatin $\mathrm{C}$ and TIM-1, which are established markers of tubular injury and lower urine concentrations of small $\mathrm{N}$-containing compounds including amino acids. Contrary to our hypothesis, the amino acid compositions in plasma and urine did not reflect the content of amino acids in the cod protein diet and in the control diet. In addition, the lower TIM-1 concentration in kidneys from COD-fed rats supports the assumption that cod proteins may protect against tubular damage. Cod protein may, therefore, 
have the potential to delay the development of kidney damage in obese Zucker rats. The beneficial effects of the COD diet may be a result of improved glucose control as we have previously shown that these COD-fed rats had lower postprandial glucose concentration compared with CAS-fed rats ${ }^{(40)}$ or through ACEinhibitory effects of the cod protein. Also, the COD diet seems to improve protein utilisation and thus the growth of young rats. Obesity is associated with proteinuria and focal segmental glomerulosclerosis and increases the risk of developing renal disease in both humans and rats ${ }^{(4-7,14)}$, and therefore, the findings of the present study may also be applicable to humans and merit further investigation.

\section{Acknowledgements}

This work was supported by the Bergen Medical Research Foundation and the Regional Research Fund of Western Norway (project no. 212625). These sponsors were not involved in the design of the study, data collection, analysis and interpretation of data, writing of the article or in the decision to submit the article for publication.

I. H. and O. A. G. formulated the research question and designed the study. A. D. and O. A. G. conducted the animal study. A. D., Ø. M., A. M., P. M. U. and O. A. G. analysed the data and performed statistical analyses. O. A. G. drafted the manuscript and had primary responsibility for the final content. All authors have contributed to the writing and approved the final manuscript.

I. H. is CEO and Chairman of Blue Protein, a company that commercialises new products based on fish proteins from fish rest raw materials. Blue Protein was not involved in on-site data collection or analyses and interpretation of the data. I. H. is a minor shareholder in Seagarden AS. The other authors declared no conflicts of interest.

\section{Supplementary material}

For supplementary material/s referred to in this article, please visit https://doi.org/10.1017/S0007114518002076

\section{References}

1. Eknoyan G, Lameire N, Barsoum R, et al. (2004) The burden of kidney disease: improving global outcomes. Kidney Int $\mathbf{6 6}$, 1310-1314.

2. Wang Y, Chen X, Song Y, et al. (2008) Association between obesity and kidney disease: a systematic review and metaanalysis. Kidney Int 73, 19-33.

3. Maric-Bilkan C (2013) Obesity and diabetic kidney disease. Med Clin North Am 97, 59-74.

4. Global Burden of Metabolic Risk Factors for Chronic Diseases Collaboration (2014) Cardiovascular disease, chronic kidney disease, and diabetes mortality burden of cardiometabolic risk factors from 1980 to 2010: a comparative risk assessment. Lancet Diabetes Endocrinol 2, 634-647.

5. Chertow GM, Hsu CY \& Johansen KL (2006) The enlarging body of evidence: obesity and chronic kidney disease. $\mathrm{J} \mathrm{Am}$ Soc Nephrol 17, 1501-1502.
6. D'Agati VD, Chagnac A, de Vries AP, et al. (2016) Obesityrelated glomerulopathy: clinical and pathologic characteristics and pathogenesis. Nat Rev Nephrol 12, 453-471.

7. Ting SM, Nair H, Ching I, et al. (2009) Overweight, obesity and chronic kidney disease. Nephron Clin Pract 112, c121-c127; discussion $\mathrm{c} 127$.

8. World Health Organization (2016) Obesity and Overweight. Fact sheet. Geneva: WHO

9. Kopple JD (2001) National kidney foundation K/DOQI clinical practice guidelines for nutrition in chronic renal failure. Am J Kidney Dis 37, S66-S70.

10. Kdoqi Work Group (2009) KDOQI clinical practice guideline for nutrition in children with CKD: 2008 update. Executive summary. Am J Kidney Dis 53, S11-S104.

11. Gopinath B, Harris DC, Flood VM, et al. (2011) Consumption of long-chain $n$-3 PUFA, alpha-linolenic acid and fish is associated with the prevalence of chronic kidney disease. $\mathrm{BrJ}$ Nutr 105, 1361-1368.

12. Mollsten AV, Dahlquist GG, Stattin EL, et al. (2001) Higher intakes of fish protein are related to a lower risk of microalbuminuria in young Swedish type 1 diabetic patients. Diabetes Care 24, 805-810.

13. de Artinano AA \& Castro MM (2009) Experimental rat models to study the metabolic syndrome. Br J Nutr $\mathbf{1 0 2}$, $1246-1253$

14. Stevenson FT, Wheeldon CM, Gades MD, et al. (2001) Hyperphagia as a mediator of renal disease initiation in obese Zucker rats. Obes Res 9, 492-499.

15. Zucker LM (1965) Hereditary obesity in the rat associated with hyperlipemia. Ann N Y Acad Sci 131, 447-458.

16. Coimbra TM, Janssen U, Grone HJ, et al. (2000) Early events leading to renal injury in obese Zucker (fatty) rats with type II diabetes. Kidney Int 57, 167-182.

17. Lavaud S, Michel O, Sassy-Prigent C, et al. (1996) Early influx of glomerular macrophages precedes glomerulosclerosis in the obese Zucker rat model. I Am Soc Nephrol 7, 2604-2615.

18. Laping NJ, Olson BA, Day JR, et al. (1998) The age-related increase in renal clusterin mRNA is accelerated in obese Zucker rats. J Am Soc Nephrol 9, 38-45.

19. Kasiske BL, O'Donnell MP \& Keane WF (1992) The Zucker rat model of obesity, insulin resistance, hyperlipidemia, and renal injury. Hypertension 19, I110-I115.

20. Kasiske BL, Cleary MP, O'Donnell MP, et al. (1985) Effects of genetic obesity on renal structure and function in the Zucker rat. J Lab Clin Med 106, 598-604.

21. Kris-Etherton PM, Harris WS \& Appel LJ (2002) Fish consumption, fish oil, omega-3 fatty acids, and cardiovascular disease. Circulation 106, 2747-2757.

22. The Norwegian Directorate of Health (2014) Anbefalinger om kosthold, ernæring og fysisk aktivitet (Recommendations regarding diet, nutrition and physical activity). Report no IS2170. https://helsedirektoratet.no/publikasjoner/anbefalingerom-kosthold-ernering-og-fysisk-aktivitet

23. Fulgoni VL 3rd (2008) Current protein intake in America: analysis of the National Health and Nutrition Examination Survey, 2003-2004. Am J Clin Nutr 87, 1554S-1557S.

24. The Norwegian Directorate of Health (2012) Norkost 3 - En landsomfattende kostholdsundersøkelse blant menn og kvinner i Norge i alderen 18-70 år, 2010-2011 (Norkost 3, national dietary survey conducted among adults in Norway aged 18-70 years 2010-2011). Report no IS-2000. https://helsedirektoratet. no/publikasjoner/norkost-3-en-landsomfattende-kostholdsundersokelse-blant-menn-og-kvinner-i-norge-i-alderen-1870-ar201011 
25. Iritani N, Narita R, Fujita T, et al. (1985) Effects of dietary fish protein, soybean protein and casein on cholesterol turnover in rats. J Nutr Sci Vitaminol 31, 385-392.

26. Demonty I, Deshaies Y \& Jacques H (1998) Dietary proteins modulate the effects of fish oil on triglyceridemia in the rat. Lipids 33, 913-921.

27. Zhang X \& Beynen AC (1993) Influence of dietary fish proteins on plasma and liver cholesterol concentrations in rats. $\mathrm{Br}$ J Nutr 69, 767-777.

28. Lavigne C, Marette A \& Jacques H (2000) Cod and soy proteins compared with casein improve glucose tolerance and insulin sensitivity in rats. Am J Physiol Endocrinol Metab 278, E491-E500.

29. Lavigne C, Tremblay F, Asselin G, et al. (2001) Prevention of skeletal muscle insulin resistance by dietary cod protein in high fat-fed rats. Am J Physiol Endocrinol Metab 281, E62-E71.

30. Ait-Yahia D, Madani S, Savelli JL, et al. (2003) Dietary fish protein lowers blood pressure and alters tissue polyunsaturated fatty acid composition in spontaneously hypertensive rats. Nutrition 19, 342-346.

31. Shukla A, Bettzieche A, Hirche F, et al. (2006) Dietary fish protein alters blood lipid concentrations and hepatic genes involved in cholesterol homeostasis in the rat model. Br J Nutr 96, 674-682.

32. Kato M, Ogawa H, Kishida T, et al. (2009) The mechanism of the cholesterol-lowering effect of water-insoluble fish protein in ovariectomised rats. Br J Nutr 102, 816-824.

33. Liaset B, Madsen L, Hao Q, et al. (2009) Fish protein hydrolysate elevates plasma bile acids and reduces visceral adipose tissue mass in rats. Biochim Biophys Acta 1791, 254-262.

34. Pilon G, Ruzzin J, Rioux LE, et al. (2011) Differential effects of various fish proteins in altering body weight, adiposity, inflammatory status, and insulin sensitivity in high-fat-fed rats. Metabolism 60, 1122-1130.

35. Madani Z, Louchami K, Sener A, et al. (2012) Dietary sardine protein lowers insulin resistance, leptin and TNF-alpha and beneficially affects adipose tissue oxidative stress in rats with fructose-induced metabolic syndrome. Int J Mol Med 29, 311-318.

36. Gudbrandsen OA, Wergedahl H, Liaset B, et al. (2005) Dietary proteins with high isoflavone content or low methionineglycine and lysine-arginine ratios are hypocholesterolaemic and lower the plasma homocysteine level in male Zucker fa/ fa rats. BrJ Nutr 94, 321-330.

37. Hurley C, Galibois I \& Jacques H (1995) Fasting and postprandial lipid and glucose metabolism are modulated by dietary proteins and carbohydrates: role of plasma insulin concentrations. J Nutr Biochem 6, 540-546.

38. Wergedahl H, Liaset B, Gudbrandsen OA, et al. (2004) Fish protein hydrolysate reduces plasma total cholesterol, increases the proportion of HDL cholesterol, and lowers acyl-CoA: cholesterol acyltransferase activity in liver of Zucker rats. J Nutr 134, 1320-1327.

39. Reeves PG, Nielsen FH \& Fahey GC Jr (1993) AIN-93 purified diets for laboratory rodents: final report of the American Institute of Nutrition ad hoc writing committee on the reformulation of the AIN-76A rodent diet. J Nutr $\mathbf{1 2 3}$, 1939-1951.

40. Drotningsvik A, Mjos SA, Hogoy I, et al. (2015) A low dietary intake of cod protein is sufficient to increase growth, improve serum and tissue fatty acid compositions, and lower serum postprandial glucose and fasting non-esterified fatty acid concentrations in obese Zucker fa/fa rats. Eur J Nutr $\mathbf{5 4}$ 1151-1160.
41. Vikoren LA, Nygard OK, Lied E, et al. (2013) A randomised study on the effects of fish protein supplement on glucose tolerance, lipids and body composition in overweight adults. Br J Nutr 109, 648-657.

42. Ouellet V, Marois J, Weisnagel SJ, et al. (2007) Dietary cod protein improves insulin sensitivity in insulin-resistant men and women: a randomized controlled trial. Diabetes Care $\mathbf{3 0}$, 2816-2821.

43. Drotningsvik A, Pampanin DM, Slizyte R, et al. (2018) Hydrolyzed proteins from herring and salmon rest raw material contain peptide motifs with angiotensin-I converting enzyme inhibitors and resulted in lower urine concentrations of protein, cystatin $\mathrm{C}$ and glucose when fed to obese Zucker fa/fa rats. Nutr Res 52, 14-21.

44. Vikoren LA, Drotningsvik A, Mwakimonga A, et al. (2018) Diets containing salmon fillet delay development of high blood pressure and hyperfusion damage in kidneys in obese Zucker fa/fa rats. J Am Soc Hypertens 12, 294-302.

45. Reeves PG (1996) AIN-93 purified diets for the study of trace element metabolism in rodents. In Trace Elements in Laboratory Rodents, pp. 3-37 [RR Watson, editor]. Boca Raton FL: CRC Press Inc.

46. Conway EJ \& Byrne A (1933) An absorption apparatus for the micro-determination of certain volatile substances: the micro-determination of ammonia. Biochem J 27, 419-429.

47. Shalaby SM, Zakora M \& Otte J (2006) Performance of two commonly used angiotensin-converting enzyme inhibition assays using FA-PGG and HHL as substrates. J Dairy Res $\mathbf{7 3}$, 178-186.

48. Midttun O, Kvalheim G \& Ueland PM (2013) High-throughput, low-volume, multianalyte quantification of plasma metabolites related to one-carbon metabolism using HPLC-MS/MS. Anal Bioanal Chem 405, 2009-2017.

49. Midttun O, McCann A, Aarseth O, et al. (2016) Combined measurement of 6 fat-soluble vitamins and 26 water-soluble functional vitamin markers and amino acids in $50 \mu \mathrm{l}$ of serum or plasma by high-throughput mass spectrometry. Anal Chem 88, 10427-10436.

50. Midttun O, Hustad S \& Ueland PM (2009) Quantitative profiling of biomarkers related to B-vitamin status, tryptophan metabolism and inflammation in human plasma by liquid chromatography/tandem mass spectrometry. Rapid Commun Mass Spectrom 23, 1371-1379.

51. Bradford MM (1976) A rapid and sensitive method for the quantitation of microgram quantities of protein utilizing the principle of protein-dye binding. Anal Biochem $\mathbf{7 2}$, 248-254.

52. McCoy RH (1949) Dietary requirements of the rat. In The Rat in Laboratory Investigation, pp. 67-101 [JQ Griffith and EJ Farris, editors]. Philadelphia, PA: J. B. Lippincott Company.

53. Gross JL, de Azevedo MJ, Silveiro SP, et al. (2005) Diabetic nephropathy: diagnosis, prevention, and treatment. Diabetes Care 28, 164-176.

54. Betts PR \& Green A (1977) Plasma and urine amino acid concentrations in children with chronic renal insufficiency. Nephron 18, 132-139.

55. Macpherson NA, Moscarello MA \& Goldberg DM (1991) Aminoaciduria is an earlier index of renal tubular damage than conventional renal disease markers in the gentamicin-rat model of acute renal failure. Clin Invest Med 14, 101-110.

56. Conti M, Moutereau S, Zater M, et al. (2006) Urinary cystatin C as a specific marker of tubular dysfunction. Clin Chem Lab Med 44, 288-291.

57. Satoh-Asahara N, Suganami T, Majima T, et al. (2011) Urinary cystatin $\mathrm{C}$ as a potential risk marker for cardiovascular disease 
and chronic kidney disease in patients with obesity and metabolic syndrome. Clin J Am Soc Nephrol 6, 265-273.

58. Togashi Y \& Miyamoto Y (2013) Urinary cystatin C as a biomarker for diabetic nephropathy and its immunohistochemical localization in kidney in Zucker diabetic fatty (ZDF) rats. Exp Toxicol Pathol 65, 615-622.

59. Han WK, Waikar SS, Johnson A, et al. (2008) Urinary biomarkers in the early diagnosis of acute kidney injury. Kidney Int 73, 863-869.

60. van Timmeren MM, van den Heuvel MC, Bailly V, et al. (2007) Tubular kidney injury molecule-1 (KIM-1) in human renal disease. J Pathol 212, 209-217.

61. Chiusolo A, Defazio R, Zanetti E, et al. (2010) Kidney injury molecule-1 expression in rat proximal tubule after treatment with segment-specific nephrotoxicants: a tool for early screening of potential kidney toxicity. Toxicol Pathol 38, $338-345$.

62. Stevens LA, Coresh J, Greene T, et al. (2006) Assessing kidney function - measured and estimated glomerular filtration rate. $N$ Engl J Med 354, 2473-2483.

63. Star RA (1998) Treatment of acute renal failure. Kidney Int 54, 1817-1831.

64. Pucci L, Triscornia S, Lucchesi D, et al. (2007) Cystatin C and estimates of renal function: searching for a better measure of kidney function in diabetic patients. Clin Chem $\mathbf{5 3}$, 480-488.

65. Garibotto G, Sofia A, Saffioti S, et al. (2010) Amino acid and protein metabolism in the human kidney and in patients with chronic kidney disease. Clin Nutr 29, 424-433.

66. Woolf LI \& Giles HM (1956) Urinary excretion of amino-acids and sugar in the nephrotic syndrome; a chromatographic study. Acta Paediatr 45, 489-500.

67. van Waarde A (1988) Biochemistry of non-protein nitrogenous compounds in fish including the use of amino acids for anaerobic energy production. Comp Biochem Physiol B Comp Biochem 91B, 207-228.

68. Tamaki N, Iizumi H, Masumitu N, et al. (1976) Species specificity on the contents of anserine and carnosine. Yakugaku Zasshi 96, 1481-1486.

69. Davey CL (1960) The significance of carnosine and anserine in striated skeletal muscle. Arch Biochem Biophys 89, 303-308.

70. Forde-Skjaervik O, Skjaervik O, Morkore T, et al. (2006) Dietary influence on quality of farmed Atlantic cod (Gadus morhua): effect on glycolysis and buffering capacity in white muscle. Aquaculture 252, 409-420.

71. Altorf-van der Kuil W, Brink EJ, Boetje M, et al. (2013) Identification of biomarkers for intake of protein from meat, dairy products and grains: a controlled dietary intervention study. Br J Nutr 110, 810-822.

72. Clark JF (1998) Creatine: a review of its nutritional applications in sport. Nutrition 14, 322-324.

73. Cho CE, Taesuwan S, Malysheva OV, et al. (2017) Trimethylamine- $N$-oxide (TMAO) response to animal source foods varies among healthy young men and is influenced by their gut microbiota composition: a randomized controlled trial. Mol Nutr Food Res 61, DOI: 10.1002/mnfr.201600324.

74. Taes YE, Delanghe JR, Wuyts B, et al. (2003) Creatine supplementation does not affect kidney function in an animal model with pre-existing renal failure. Nephrol Dial Transplant 18, 258-264.

75. Ellery SJ, LaRosa DA, Kett MM, et al. (2016) Dietary creatine supplementation during pregnancy: a study on the effects of creatine supplementation on creatine homeostasis and renal excretory function in spiny mice. Amino Acids 48, 1819-1830.

76. Zeisel SH \& Warrier M (2017) Trimethylamine $N$-oxide, the microbiome, and heart and kidney disease. Annu Rev Nutr 37, 157-181.

77. Molitch ME, DeFronzo RA, Franz MJ, et al. (2004) Nephropathy in diabetes. Diabetes Care 27, Suppl. 1, S79-S83.

78. Lewis EJ, Hunsicker LG, Clarke WR, et al. (2001) Renoprotective effect of the angiotensin-receptor antagonist irbesartan in patients with nephropathy due to type 2 diabetes. $N$ Engl J Med 345, 851-860.

79. Lewis EJ, Hunsicker LG, Bain RP, et al. (1993) The effect of angiotensin-converting-enzyme inhibition on diabetic nephropathy. The Collaborative Study Group. $N$ Engl J Med 329, $1456-1462$.

80. Anderson S, Rennke HG \& Brenner BM (1986) Therapeutic advantage of converting enzyme inhibitors in arresting progressive renal disease associated with systemic hypertension in the rat. J Clin Invest 77, 1993-2000.

81. Brewster UC \& Perazella MA (2004) The renin-angiotensinaldosterone system and the kidney: effects on kidney disease. Am J Med 116, 263-272.

82. Ngo DH, Vo TS, Ngo DN, et al. (2012) Biological activities and potential health benefits of bioactive peptides derived from marine organisms. Int J Biol Macromol 51, 378-383. 